\title{
Thoughts on the Reform of Teaching Law
}

\author{
Li Junfei ${ }^{1, a^{*}}$, Zhao Longhai ${ }^{2, b}$ \\ ${ }^{1}$ Department of Information Engineering, Shanwei Polytechnic, Shanwei, Guangdong province, China \\ ${ }^{2}$ Department of Information Engineering, Shanwei Polytechnic, Shanwei, Guangdong province, China \\ a*lijunfei@jssvc.edu.cn \\ ${ }^{b}$ tianjin02@126.com
}

\begin{abstract}
This article discusses the teaching method reform of the " Three Education Reforms " in Chinese higher vocational colleges, and focuses on the problems existing on teaching project and teaching information, and put forward solutions. This article has a certain reference value of the " Three Education Reform " in China.
\end{abstract}

Keywords: Teaching method, Reform, Project-based, Informatization

\section{INTRODUCTION}

In 2019, the State Council of China issued the "National Vocational Education Reform Implementation Plan", which pointed out the direction for our development of vocational education.

The "Three Education Reforms" is an overall reform of teachers, teaching materials and teaching methods, and is the core content of the comprehensive reform of higher vocational education in China at this stage.

Teachers, teaching materials and teaching methods are mutually fettered and assisted. Among them, teachers are the main body of the reforms, teaching materials are the carriers of the reforms, and teaching methods are the path of the reforms. The reform of teachers and teaching materials needs to be realized through the reform of teaching methods.

Therefore, the reform of teaching methods is the core of the "Three Education Reforms".

By strengthening the classroom position, improving the level of information, docking scientific and technological development with market demand, training high-quality workers and technical skills talents, the reform of teaching methods will effectively improve the quality of higher vocational education [1].

There are many articles of the reform of the teaching method of the " Three Education Reforms " which had put forward their own views.

By summarizing the main points of these mainstream views, one is that higher vocational teaching should realize project-based teaching, and the other is that higher vocational teaching should be informatized and use the most advanced information technology. This article puts forward some thoughts on them.

\section{TEACHING PROJECTIZATION}

For the project-based teaching of higher vocational education, many scholars have put forward requirements to build a learner-centered education ecology, which is required to take students' development as the center and students' learning as the center, and set up a learnercentered curriculum to satisfy learners' free growth, selfrealization and the formation of a complete personality[2][3].

For those, teachers are required to change their identities and roles, and evolve from a traditional lecturetype teacher to a coach.

Teachers are required to develop the four major abilities of coaching: teaching is realized by listening, asking, distinguishing and responding. At the same time, the four major roles of coaching must be fulfilled for teachers: realizing the functions of mirror, compass, catalyst and key in teaching.

Because of these reasons, the teaching methods are required for changing: in the teaching, the subject system must be turned to the action system, and the subject knowledge structure system must be turned to the work process structure system, which require the establishment of action-oriented project-based teaching.

One of the basic issues involved in project-based teaching is the construction of laboratories. 
Nowadays, many higher vocational colleges in China are upgraded or merged with secondary vocational schools, which brings about some problems. For example, the head of the department is born in a nonprofessional field and does not understand the relevant professional field knowledge; the technologies are updated too fast and the knowledge of professional teachers cannot keep up with technological developments.

Therefore, there are many problems of laboratory construction.

\subsection{Expertise not Matching Laboratory Construction}

Professional teachers' knowledge is not updated enough, but due to the demand of technology and market for higher vocational graduates, higher vocational colleges need to take new courses and build new laboratories.

In this case, professional teachers' preliminary inspection for new equipment is easy to be fooled by manufacturers, and the imported experimental equipment often cannot adapt to the corresponding teaching functions.

Sometimes, in order to make the laboratory beautiful or hope to win the praise of the leaders, some teachers put forward unreasonable changes of equipments in the purchase with manufacturers.

In order to sell equipments, manufacturers generally unconditionally agree to any change requirements for equipment, which result in the electrical performance of the modified experimental equipments not being able to pass the test, the experimental equipments cannot be used or often are unstable during the experiment teaching process, and the manufacturers themselves often cannot solve these problems.

\subsection{Equipments not Matching the Market Demand}

The equipment developed by many teaching equipment manufacturers is specially developed to sell to schools, the function of the equipments is disjointed with the actual work needs of enterprises.

There are often no relevant supporting textbooks and experimental instruction book for these equipments, even if there are, the experimental instructions and experimental procedures are constantly wrong, which makes it impossible to run through these procedures in teaching.

Manufacturers often cannot solve these problems because of frequent resignation of technicians.

\subsection{Corruption in Transactions}

The development of higher vocational colleges needs to be closely integrated with the market and strengthen school-enterprise cooperation.

However, some distortions have appeared in the development process of China. The managers of some higher vocational colleges at all level have formed a relationship of interest transmission of these schoolenterprise cooperative enterprises.

For example, when some schools purchase experimental equipments, They do not directly purchase the products of the manufacturer, but let the schoolenterprise cooperation enterprise to buy equipments as an intermediary. The prestigious name for this way is said it will be easy to find the manufacturers to maintain in the future. This leads to a lot of intermediate gray interests.

\subsection{Knowledge not Matching Experimental Teaching}

Because the knowledge update of professional teachers cannot keep up with the technological development, after the completion of the laboratory, the teachers are very confused with the usage of experimental equipments .

Although the so-called training by the manufacturer is cultivated, the teacher truly masters the performance of a set of experimental equipment that will take a long time.

There have been teachers that spent a semester in a new laboratory without knowing there were some problems with the equipments. Teachers and students are all in a muddle of lessons.

\subsection{Management System not Matching Development}

The existing management system of higher vocational colleges results in that in the process of laboratory construction, some experimental equipments that have cost more than one million yuan will break down after two or three years, which cannot be repaired and can only be put there for decoration, this is still a good situation.

In extreme cases, under the influence of teachers' seniority and small groupism, if a teacher finds equipment problems, sometimes instead of solving the experimental equipment problems, dumping mode will happen, the leaders do not investigate the responsibility of the purchaser, but let the teacher who found the problem to sign the acceptance and admit that the equipment is no problems.

Therefore, the project-based teaching in Chinese higher vocational colleges must not only solve the problems of teaching methods, but also solve the 
problems of laboratory construction and the management system of higher vocational colleges.

\section{INFORMATIZATION OF TEACHING}

The rapid development of "Internet + Learning" has provided unprecedented technical support for the promotion of learners' self-learning.

Some scholars put forward the proposition of "Help Learning Courses", which is a new understanding of modern higher vocational education on the basis of teaching information, which believes that modern education is a social activity that helps students for learning, and higher vocational education is to help students for constructing a specific professional cognitive model in the brain.

The so-called learning means that students build professional cognitive models in their own minds, and the so-called teaching means that teachers help students build professional cognitive models.

The characteristics are: sudent-centered, teachers help, learn to help, to help learn.

The main points are: students use new information technologies to learn independently, and teachers are subordinate to the role of helping learning [4].

\subsection{Inspection of Information by Epidemic}

The severe epidemic in China in the spring of 2020 has caused many schools to postpone the opening of classes.

In order to avoid delaying students' studies, many higher vocational colleges have used various "Internet + Learning" technologies to conduct online teaching, such as QQ video and Dingding, Video, tencent conferences, etc, which have achieved a similar purpose of "Help Learning Courses", which is also equivalent to a test of teaching information.

How is the teaching effect of higher vocational education on this way?

\subsection{Current Situation of Students Quality}

First of all, there is a premise.

With the continuous expansion of colleges and universities in China, the quality of students in higher vocational colleges has been declining rapidly, and the sources of students are becoming diversified. Many schools can enroll students through registration system now, and the learning ability and cultural quality of students are getting lower and lower.

Many vocational students are generally tired of studying and are obsessed with computer games all day long.
Psychological problems are also becoming more and more common to vocational students.

Some students come to school only at the request for their parents, many just for getting a diploma, and some students don't care whether they graduate or not.

\subsection{Effect of Informationization Teaching}

Most of the courses of the higher vocational college where the author worked have also adopted the online teaching model.

After the term begins in 2020, the author conducted an investigation into the situation of online learning among students.

Many students said privately: Sir, don't tell the school leaders that we opened the online teaching there, and rarely look at it, this teaching method has no effect at all.

After semester starts in the second half of the 2020, the effect of online teaching in the first half of 2020 has received further feedback from students' learning situation.

Here is an example of a three-year higher vocational students.

The students that enter the higher vocational school from the secondary vocational school have generally poor self-consciousness, in the previous online teaching, they are very little real learning, because of poor professional foundation, it's difficult for them to learn a new lesson, the teachers had to make up for the previous lessons while teaching the new lesson.

The Students who enter higher vocational colleges from ordinary high schools have good studied habits, about one-third of them have studied hard in the previous online teaching and laid a certain foundation, when new classes are taught, the degree of students accepting new knowledge is relatively better.

\section{CONCLUSION}

Higher vocational education is a key education to serve social and economic development. The teaching method reform of the "Three Education Reform" is the link between teachers and teaching materials.

With effective teaching methods, it is helpful to stimulate students' self-learning consciousness and improve the teaching effect.

However, from the analysis of the above two mainstream teaching reform methods: teaching project and teaching information, we can see that there are still many problems. In this regard, the author puts forward two reference suggestions. 


\subsection{School-enterprise Cooperative Laboratory Construction}

In order to realize student-centered projected teaching, higher vocational colleges should carry out school-enterprise cooperative laboratory construction.

It is necessary for schools and enterprises to build laboratories together. Nowadays, in some schoolenterprise cooperation, students' experiments and training are moved to the enterprise, but this pattern is unique, it would be difficult for all majors of the entire school to do this.

The school-enterprise co-construction of laboratories must realize the joint funding and construction of the school and the enterprise, and the laboratories and experimental equipment must truly meet the actual work needs of the first-line enterprises, rather than a so-called teaching instrument.

Only in this way can the vocational colleges realize the real docking between the ability of the students they cultivate and the social needs.

Through the laboratory and training room in cooperation with schools and enterprises, schools and enterprises jointly design teaching plans, teaching schemes and evaluation methods, develop teaching projects that integrate industry and education, and integrate production and education to realize projectbased teaching. [5].

\subsection{Informationized Teaching under Real-time Supervision}

To put students under real-time supervision and pressure, higher vocational colleges must realize the reform of teaching information in this way.

According to the specific situation of the existing students in Chinese higher vocational education, the reform of teaching information must have real-time monitoring of students' teaching.

It is impossible to do a good job of teaching in higher vocational education by guiding students to learn from the perspective of encouraging students to have an active interest in learning.

There is no such thing as a happy education, and it is absurd, as has long been confirmed by comparisons of teaching in public and private schools around the world.

While using modern information technology for new teaching, teachers' real-time pressure monitoring must be added. New technologies such as virtual reality, augmented reality, and mixed reality are more conducive to this realization when implementing hybrid, interactive, and social learning modes.
However, the development of such teaching methods and learning methods requires a lot of work, which is a gradual process of development. This will be a development direction of the reform of teaching information.[6].

\section{REFERENCES}

[1] Yu Fang, Jiang Caiyun, 2020, A Preliminary Study on the Reform of Teaching Method under the Background of the Construction of "Double High Plan", Journal of Jiangsu Vocational and Technical College of Economics and Trade, vol. 5, pp. 83-85.

[2] Tang Zhibin, Ouyang He, Ren Chenwei, 2017,"Learner-centered": On the Reform of Modern Talent Training Mode in Vocational Education, Vocational Education Forum, vol. 34, pp. 14-19.

[3] Qi Hongli, 2017, True Survival and Life Skills Education, Chinese Vocational and Technical Education, vol. 3, pp. 64-67.

[4] Ouyang He, Dai Chuntao, 2017, The Connotation, Motivation and Promotion Strategy of the Integration of Industry and Education, Education and Career, vol. 7, pp. 51-56.

[5] Tang Jianxin, 2021, Exploration of Laboratory Construction Project Management in Higher Vocational Colleges Based on the Whole Life Cycle, Modern Vocational Education, vol. 4, pp. 208-209.

[6] Tang Ming, 2020, Exploration and Analysis of the Reform of "Three Educations" in Vocational Education under the Guidance of Wisdom Education, Exploration of Higher Vocational Education, vol. 4, pp. 74-79. 